https://helda.helsinki.fi

\title{
Foucault and Soviet Biopolitics
}

\section{Prozorov, Sergei}

2014-12-10

Prozorov , S 2014 , ' Foucault and Soviet Biopolitics ' , History of the Human Sciences , vol. 27 , no. 5 , pp. 6-25 . https://doi.org/10.1177/0952695114537636

http://hdl.handle.net/10138/233451

https://doi.org/10.1177/0952695114537636

acceptedVersion

Downloaded from Helda, University of Helsinki institutional repository.

This is an electronic reprint of the original article.

This reprint may differ from the original in pagination and typographic detail.

Please cite the original version. 
This is a post-peer-review, pre-copyedit version of an article published in History of the Human Sciences, vol. 27, issue 5. The final authenticated version is available online at: https://doi.org/10.1177/0952695114537636.

Sergei Prozorov

FOUCAULT AND SOVIET BIOPOLITICS

Introduction

The Foucauldian problematic of biopolitics has become an increasingly influential research orientation in the social sciences, applied in a variety of disciplines to analyse the transformations in the rationalities of power over life in diverse spatio-temporal contexts. The two primary contexts for these studies have been liberalism, particularly post-World War II neoliberalism, and fascism, particularly German Nazism (see Agamben, 1998; Esposito, 2008; Lemke, 2011). What has been almost entirely missing is the third major political ideology of the $20^{\text {th }}$ century, i.e. socialism, particularly in its Soviet version (for exceptions see Collier 2011, Hoffmann 2011). There have been numerous studies of the positive and productive orientation of neoliberal biopolitics that governs lives through the mobilization of the freedom of its subjects and the negative and destructive orientation of Nazi biopolitics that engages in paroxysmal violence in the name of the survival of the privileged race and ultimately threatens its very existence. Yet, the studies of biopolitics are all but silent about what was arguably the most ambitious project of the positive transformation of human lives, i.e. the creation of the 'New Soviet Person' as the emancipated subject of the socialist society, which at the same time unleashed the unprecedented negativity of terror against the very persons that were to be transformed. The Soviet experience thus provides ample 
historical evidence of both the positive and negative aspects of biopolitics, its power to 'make live' and to 'let die' (Foucault, 2003: 241). Nonetheless, this evidence is either ignored as irrelevant to the Western biopolitical tradition or ends up subsumed under the rubric of totalitarianism as largely analogous to the Nazi experience (Tismaneanu, 2012. See Losurdo, 2004 for a critique).

In fact, this lack of interest in Soviet biopolitics may be traced back to the original articulation of the problematic in the 1970s' work of Michel Foucault. In this article we shall address Foucault's reading of Soviet socialism from a biopolitical perspective and critically re-engage with his subsumption of the Soviet case under Western modes of biopolitics, the move that has since then been regularly repeated in contemporary studies (see e.g. Hoffmann, 2011: 309-313). Two methodological caveats regarding this task are in order. Firstly, since Foucault never addressed Russian or Soviet politics in any detailed manner, the textual corpus we are dealing with is necessarily scant, composed of brief forays in books, digressions in lectures, casual asides in interviews, etc. The 1975-1976 lecture course at the College de France 'Society Must be Defended' offers the most extensive treatment of the Soviet case in all of Foucault's writings, hence it will be the main focus of our analysis. Yet, while the textual corpus in question is scant, it is in no way incoherent, since, as we shall show, Foucault practiced the same move of the subsumption of the Soviet experience under Western rationalities in a variety of contexts during the 1970s: from aesthetics to labour relations, from psychiatry to concentration camps. While the accuracy of this move should be assessed in each case individually, what we are interested in is rather the logic that authorizes such a subsumption and its implications for understanding the phenomenon of Soviet socialism. We shall therefore begin by addressing Foucault' general interpretation of Soviet socialism in the period when his theories of biopolitics and governmentality were articulated and then proceed to the more detailed analysis of his more systematic treatment of the Soviet case in 
'Society must be Defended', where he subsumes the Soviet biopolitical rationality under the paradigm of racism, which defined the entire Western biopolitical tradition and reached its extreme point in Nazism.

The second caveat is that while we shall take issue with Foucault's diagnosis and argue that the concept of racism has only a loose metaphorical applicability to Soviet biopolitics and its thanatopolitical conversion, our argument is not intended as criticism of Foucault, who, after all, never undertook a proper analysis of the Soviet case. In a famous interview 'Questions of Geography' Foucault plausibly protested, before conceding at the very end, that he did not have to include geography or any other science into his archaeological project: 'One can perfectly well not talk about something because one doesn't know about it, not because one has a knowledge, which is unconscious and therefore inaccessible.' (Foucault, 1980b: 66) Even if Foucault did talk about socialism, albeit understandably with less interest and less rigour than he did about the key areas of his research, we shall bracket off the hermeneutics of suspicion and not search for a hidden reason why Foucault said what he said about the Soviet case. We are more interested in what possibilities the Foucauldian approach to biopolitics offers in advancing beyond his own contributions to the question of Soviet biopolitics. For this reason, after demonstrating that Foucault's concept of racism is ill-fitted for grasping the specificity of socialist biopolitics and its thanatopolitical conversion under Stalinism, we shall revisit the genealogy of racism in 'Society Must be Defended' in order to isolate a biopolitical rationality that was mentioned yet remained obscure in Foucault's analysis. This is the revolutionary biopolitics of class struggle, which is irreducible to the state racism of the $19^{\text {th }}$ century and its extreme descendant in Nazism and is best exemplified by the policies of the Stalinist 'Great Break' (1928-1932). The problems with Foucault's statements about Soviet biopolitics therefore do not render his approach inapplicable 
or misleading, but rather, in full accordance with Foucault's own characterization of his theory as a 'toolkit' (Foucault, 1980a: 145), call for a reengagement with and adaptation of this approach in the light of the evidence from the Soviet experience.

The Conservatism of Soviet Governmentality

Although Foucault's work on biopolitics and governmentality only addresses issues of Stalinism and Soviet politics peripherally, it was clearly influenced by the events related to them. As Jan Plamper (2002) argued in a definitive analysis of the theme of the Gulag in Foucault's work, Foucault's genealogical turn towards the questions of power and government in the early and mid-1970s unfolded in the political context dominated by the publication of Solzhenitsyn's Gulag Archipelago in French in 1974 (see also Kharkhordin, 2001). It was this publication that accelerated the drift of French intellectuals, including Foucault, away from Marxism, and contributed to the rise of the 'anti-totalitarian' new philosophers (Bernard-Henry Levy, Andre Glucksmann et al), whom Foucault briefly supported. Moreover, the revelations about the Gulag in Solzhenitsyn's work led to the increased attention in France to the dissident movement in the USSR and Eastern Europe, which Foucault actively supported throughout the 1970s and whose struggle for freedom of speech arguably influenced his turn toward the problematic of parrhesia in the lectures of the 1980s (Foucault, 2011).

Nonetheless, despite its significance in the French intellectual-political context at the time, the Soviet case does not figure prominently in Foucault's analysis of biopolitics. The simplest 
explanation for this absence would be Foucault's proverbial Eurocentrism, discussed by numerous critics since the famous comment by Edward Said (1988: 9-10): 'his Eurocentrism was almost total, as if history itself took place only among a group of French and German thinkers.' And yet, such an explanation would be far too simple, since Foucault actually did discuss the Soviet Union in quite a number of articles, lectures and interviews of the 1970s (see Plamper, 2002). These texts suggest that the reason why Foucault did not analyse Soviet socialism as a specific case of biopolitics or governmentality was not his lack of interest in non-European history but rather his conviction that there was little about the Soviet case that was specific, idiosyncratic or unique. For Foucault, Soviet socialism was rather characterized by a puzzling persistence of the governmental technologies invented in late- $18^{\text {th }}$ and $19^{\text {th }}$ century Europe. Whereas on the macro-level of state ideology and socioeconomic system the USSR obviously renounced Western capitalism, on the micro-level of disciplinary and biopolitical practices it continued to follow its techniques. As early as 1971, Foucault argued that the Soviet Union 'adopted almost entirely the bourgeois value system. One gets the impression that communism in its traditional form suffers from a birth trauma: you would think that it wants to recapture for itself the world at the time it was born, the world of a triumphant bourgeoisie; communist aesthetics is realism in the style of the nineteenth century: Swan Lake, painting which tells a story, the social novel. Most of the bourgeois values are accepted and maintained by the Communist Party (in art, the family, sexuality, and daily life in general).' (Foucault in Simon, 1971: 196)

This evidence of Soviet conservatism, the proximity of Soviet socialism to the bourgeois 'value system', serves as proof of Foucault's more fundamental theoretical thesis, established during the same period, i.e. his insistence on the irreducibility of power relations to the institution of state, 
their dissemination through a myriad of 'capillary' structures that need not coalesce around the state to have determinate political effects:

I do not mean in any way to minimise the importance and effectiveness of State power. I simply feel that excessive insistence on its playing an exclusive role leads to the risk of overlooking all the mechanisms and effects of power which don't pass directly via the State apparatus, yet often sustain the State more effectively than its own institutions, enlarging and maximising its effectiveness. In Soviet society one has the example of a State apparatus which has changed hands, yet leaves social hierarchies, family life, sexuality and the body more or less as they were in capital ist society. Do you imagine the mechanisms of power that operate between technicians, foremen and workers are that much different here and in the Soviet Union? (Foucault, 1980b: 72-73)

In Foucault's view, despite the evident break with capitalist Europe in socioeconomic terms, the Soviet techniques of government were borrowed directly from its ideological antagonist, the only autochthonous addition being that of 'party discipline', whose genealogy has indeed been traced to the practices of Orthodox Christian communities (see Kharkhordin, 1999).

[It] is undoubtedly true that the Soviets, while having modified the regime of ownership and the state's role in the control of production, for the rest have simply transferred the techniques of administration and power implemented in capitalist Europe of the 19th century. The types of morality, forms of aesthetics, disciplinary methods, everything that was effectively working in bourgeois society already around 1850 has moved en bloc into the Soviet regime. Just as the Soviets have used 
Taylorism and other methods of management experimented in the West, they have adopted our disciplinary techniques, adding to our arsenal another arm - party discipline. (Foucault, 1994a : 64)

From this perspective, even the phenomenon of the Gulag, the paradigmatic site of Soviet biopolitics, appears as merely one more in the arsenal of governmental techniques borrowed by the Soviet regime from its ideological adversaries (see Engelstein, 1993). Indeed, so strong is the affinity that Solzhenitsyn's metaphor of 'archipelago', applied to the network of Soviet labour camps, was transferred by Foucault (back) to the French context as a key concept in Discipline and Punish (Foucault, 1977: 301; see also Foucault, 1980b: 68.). Foucault famously accounted for the birth of the Gulag with the help of the anecdote about a French criminologist Leveille advising the Russian government in 1892 to confine mental patients in Siberia: '[Good] old Leveille had defined the Gulag. Deportation to Siberia already existed but I believe it must have functioned quite simply as exile for political prisoners. The idea that there could be set up there a politico-medical politico-penal-medical, or medico-politico-penal - confinement, with an economic function, which would allow the exploitation of the wealth of a still virgin country, that, I think, was a new idea.' (Foucault, 1988a: 181-182. See Plamper, 2002: 269-270 for a critique) In this manner, the Gulag is inserted into the European genealogy of power relations as the 'intensification' of the logic already at work in $19^{\text {th }}$ century European governmentality (ibid.: 181). The grand opposition between liberal democracy and totalitarianism is thus rendered inoperative on the level of governmental rationality: 'After all, the organization of great parties, the development of political apparatuses, and the existence of the techniques of repression such as the camps - all that is quite clearly the heritage of liberal Western societies, and all Stalinism and fascism had to do was to stoop down and pick it up.' (Foucault, 1994b: 535, see also Foucault, 1982: 209). The Soviet 
experience is governmentally identical to the West despite being ideologically distinct from it and, given Foucault's interest in governmentality and a certain disdain for ideology, it is hardly surprising that the identity ended up more important than the difference.

\section{Biopolitics and Racism}

Let us now turn to Foucault's more extensive discussion of Soviet socialism from a biopolitical perspective in his 1975-1976 lecture course 'Society Must Be Defended'. In this course Foucault addressed the biopolitical rationality of government in terms of the logic of racism, which warranted the exclusion and ultimately the extermination of the categories of the population that were deemed other to the race in question. The theme of racism was also central to the bestknown analysis of biopolitics in the first volume of History of Sexuality (1990), published in 1976. In the subsequent lectures at the College de France $(1977-1978,1978-1979)$ the theme of racism all but disappeared, while the concept of biopolitics became rather less accentuated. In Security, Territory and Population (2007) Foucault abandoned the perspective of the modern shift from sovereign to bio-power in favour of a more extended genealogy of government from early Christianity through the Reformation to the $17^{\text {th }}$ century doctrine of the raison $d^{\prime}$ etat and $18^{\text {th }}$ century 'police science'. In The Birth of Biopolitics (2008) the term reappeared in the title, but hardly anywhere else, as Foucault concentrated on the analysis of liberal government as the 'basis on which something like biopolitics could be formed' (ibid.: 21), while repeatedly apologizing for deferring the discussion of biopolitics itself, which never actually came, since the concept disappeared entirely from Foucault's writings after these lectures (ibid.: 78, 185). 'One would be incredibly hard-pressed to find in The Birth of Biopolitics anything remotely akin to a sustained 
analysis of biopolitics.' (Hoffmann, 2014: 57) Thus, the final chapter of the first volume of the History of Sexuality and 'Society Must be Defended' remain the texts where the problematic of biopolitics is treated in the most elaborate way and will therefore be the key focus of our analysis.

In his study of (post-)Soviet biopolitics Stephen Collier contests this reading, opting to define biopolitics on the basis of Foucault's interpretation of liberalism, bracketing off the more explicit discussion in the earlier texts as 'preliminary' and 'confused' (Collier 2009: 80; 2011: 16-19). In his reading, the prefix 'bio' refers primarily to the naturalist ontology underlying liberal rationalities of government, which entails that the study of Soviet biopolitics is oriented towards the analysis of the modes of problematization of Soviet economic policy in the general sense, making the term 'biopolitics' little more than a useful shorthand for 'trade, patterns of habitation, urban conditions, means of subsistence, etc.': 'Foucault might just as well have referred to an 'econopolitics' or a 'sociopolitics' or invented a more general term. But since he did not, [...] and since biopolitics is an accepted term of art, I will stick to it.' (Collier, 2011: 17) In our reading, the ambiguity about the meaning of the concept in The Birth of Biopolitics, which contrasts with the rather more articulate notion in 'Society Must Be Defended' and History of Sexuality I, does not indicate any exit out of prior confusion but rather reflects the loss of interest and prefigures the eventual abandonment of the term, which never occurs again in Foucault's texts after 1979. This abandonment evidently does not disqualify the analyses of biopolitics made in 1976 or later: after all, Foucault abandoned concepts all the time, some more definitively than others, which has not presented their fruitful application by his successors. In our view, an analysis grounded in Foucault's 1976-1977 account of biopolitics and its thanatopolitical conversion in racism would provide a valuable complement to 
the more socioeconomic analysis of the kind undertaken by Collier, permitting us to grasp the extreme governmental violence that distinguishes particularly the Stalinist period of Soviet history.

With this caveat in mind, let us turn to the role of racism in biopolitics. In History of Sexuality I Foucault uses the concept to refer to Nazi regime as the articulation of the sovereign 'symbolics of blood' and the 'analytics of sexuality' associated with the rise of bio-power (Foucault, 1990: 149150). Foucault rejects any approach to Nazism as an abominable exception to the Western political tradition and instead treats it as a 'demonic' synthesis of sovereign and biopolitical techniques of government already operative in Western societies (Foucault, 1988b: 71). The idea of racism permits him to interpret the continuing recourse to and even intensification of state violence in the age of biopower that should apparently diminish along with the decline of the logic of sovereignty. The biopolitical logic of racism not only permits sovereign violence to survive in the climate hostile to it, but fortifies this violence by investing it with a wholly new function, no longer negative and repressive but rather oriented toward the preservation and improvement of the life of some races by annihilating the lives of the others, which pose a threat to it.

[Racism] is primarily a way of introducing a break into the domain of life that is under power's control: the break between what must live and what must die. It is a way of separating out the groups that exist within a population. This will allow power to treat that population as a mixture of races or to treat the species, to subdivide the species it controls, into the subspecies known as races. [Secondly], its role is to allow the establishment of a positive relation of this type: 'the very fact that you let more die will allow you to live more'. The enemies who have to be done away with are not adversaries in the political sense of the term; they are threats, either external or 
internal, to the population and for the population. In a normalizing society, race or racism is the precondition that makes killing acceptable. Once the state functions in the biopower mode, racism alone can justify the murderous function of the state. (Foucault, 2003: 255-256)

It is no longer a matter of what Foucault calls 'traditional racism' (ibid.: 258) that consists in mere animosity between different groups that plays no positive function in the ordering of a society. Nor is biopolitical racism merely a matter of a façade that conceals the immanent social antagonism by displacing it onto the external enemy defined in racial terms - a quasi-Marxist account of racism that Foucault deems superficial. Instead, it is a matter of the transformation in the technology of power that is more fundamental than any ideological shift: racism is what permits the state to exercise its sovereignty by enfolding it in the biopolitical context, in which killing is only legitimate when it serves to enhance the survival and health of one's own race. Thus, the indistinction between the biopolitical preoccupation with fostering life and the thanatopolitical drive for annihilation that we observe in Nazism stops being paradoxical and is graspable as an expression of the logic of racism, according to which the life of any race is fostered by its purification from other races, which 'implies both the systematic genocide of others and the risk of exposing oneself to a total sacrifice' (Foucault, 1990: 149-150).

Yet, while this account of racism is quite plausible in the case of Nazism, to what extent can it be used for understanding Soviet socialism? In the final lectures of 'Society Must Be Defended', Foucault goes beyond his above-discussed empirical claims about the reliance of socialist governmentality on the techniques developed during the rise of bio-power in $18^{\text {th }}$ and $19^{\text {th }}$ century 
Europe. Socialism is now also racist in the much more fundamental sense: 'Socialism was a racism from the outset, even in the nineteenth century. No matter whether it was Fourier at the beginning of the century or the anarchists at the end of it, you will always find a racist component in socialism.' (Foucault, 2003: 261) This is the case for two reasons. Firstly, socialism has 'made no critique of the theme of biopower' and instead has taken over 'wholesale' the fundamental idea of modern biopolitics 'that the essential function of society or the State is to take control of life, to manage it, to compensate for its aleatory nature, to explore and reduce biological accidents and possibilities' (ibid.: 261). This means that as soon as a socialist state comes to existence, it is a state 'which must exercise the right to kill or the right to eliminate, or the right to disqualify', [hence] 'racism is fully operational in the way socialist states (of the Soviet Union type) deal with the mentally ill, criminals, political adversaries, and so on' (ibid.: 262). Secondly, socialism is racist due to its emphasis on class struggle and the physical confrontation with the enemy, racism being the 'only way in which socialist thought, which is after all very much bound up with the themes of biopower, can rationalize the murder of its enemies. When it is simply a matter of eliminating an adversary in economic terms, or of taking away his privileges, there is no need for racism. Once it is a matter of coming to terms with the thought of a one-on-one encounter with the adversary, and with the need to fight him physically, to risk one's own life and to try to kill him, there is a need for racism.' (Ibid.: 262) While in the late $19^{\text {th }}$ century French context racism primarily characterized non-Marxist versions of socialism (Blanquism, anarchism, etc.) rather than strictly Marxist ones (both reformist and revolutionary), in the $20^{\text {th }}$ century it pertains primarily to the Soviet type of socialism, including the Stalinist and post-Stalinist USSR. 
Thus, in Foucault's argument, the only biopolitical specificity that Soviet socialism possesses consists precisely in the absence of any specificity, in the paradoxical and deplorable fact that for all its ideological heterogeneity to capitalist Europe it continued to rely on the biopolitical rationalities and techniques developed in it. This theme of the deficiency of socialism in its dependence on an alien logic of governmentality persists in Foucault's 1978-1979 course The Birth of Biopolitics, notwithstanding the disappearance of every reference to racism in this course and the concurrent downgrading of the problematic of biopolitics in favour of the analysis of liberalism. In this course Foucault reiterates his by now familiar claim that there is no 'autonomous governmentality of socialism' (Foucault, 2008: 93). Socialism might have a theory of the state, an economic rationality, a historical rationality, but when it comes to the rationality of government it remains reliant on those developed either in the liberal Europe or, perhaps even more so, on the pre-liberal rationalities of the police state (ibid., see also Foucault, 2007: 311-331).

[Socialism] can only be implemented connected up to diverse types of governmentality. It has been connected up to liberal governmentality, and then socialism and its forms of rationality function as counter-weights, as a corrective and a palliative to internal dangers. We have seen it function within governmentalities that would no doubt fall more under what we called the police state, a hyperadministrative state in which there is a fusion, a continuity, the constitution of a sort of massive bloc between governmentality and administration. Maybe there are still other governmentalities that socialism is connected up to; it remains to be seen. But in any case, I do not think that for the moment there is an autonomous governmentality of socialism. (Ibid.: 93) 
Since the lectures do not pursue the theme of socialism any further, we are left with a diagnosis that is similar to the one made in the context of racism, yet, now that racism is out of the picture, somewhat more noncommittal about what governmentalities socialism is 'connected up to'. Evidently, as we have seen in the first part of the article, it is possible to point to the presence of individual techniques of government that arose from both police and liberal rationalities. Yet, what remains constant in Foucault's account is the subsumption of Soviet socialism under the European experience, the insistence on the 'unhappy symbiosis' of socialism with its ideological antagonists on the biopolitical terrain (ibid.: 94).

Racism and the Great Break

We have seen how Foucault's argument in 'Society Must Be Defended' goes beyond a mere noting of similarities between Soviet and European biopolitical rationalities to argue that socialism was originally and 'authentically' racist to the extent that it was biopolitical. As soon as we enter the terrain of bio-power, every political logic, including that of class struggle and the socialist revolution, is bound to assume a racist inflection. It is this argument that we shall challenge in the three sections that follow by demonstrating, firstly, the inapplicability of the notion of racism for the Soviet regime in its early phase of the 'Great Break' (1928-1933), in which the foundations of the socialist order were constructed and which possessed an autonomous biopolitical rationality. The recourse of the Soviet regime to racism as well as other Western governmental techniques is rather intelligible in the context of what has come to be known as the 'Great Retreat' from this rationality in the mid-1930s, particularly in the policies regarding national minorities. Thirdly, we shall argue that the logic of racism is incapable of accounting for the thanatopolitical conversion of 
Soviet biopolitics in the period of High Stalinism, characterized by the use of state terror against the millions of the 'enemies of the people' (1936-1953).

Foucault's use of the concept of racism oscillates ambiguously between its literal sense, when referring to Nazism and the colonial violence of Western liberal states, and a figurative or metaphorical usage with regard to both the domestic politics of the liberal states and Soviet governmentality. In the latter case the metaphorical usage is based on the apparent similarity between the discourse of class struggle with its figure of 'class enemy' and the discourse of the struggle for the protection of the race with its correlate figure of the racial enemy: 'In Soviet State racism, what revolutionary discourse designated as the class enemy becomes a sort of biological threat. So, who is the class enemy now? Well, it's the sick, the deviant, the madman. As a result, the weapon that was once used in the struggle against the class enemy is now wielded by a medical police, which eliminates class enemies as though they were racial enemies.' (Foucault, 2003: 83. Emphasis added.). Yet, is this 'as though' justified: was the class enemy really 'a sort of' biological threat? After all, a principled rejection of racism even in its quasi-scientific eugenic guise was a permanent feature of the official Soviet discourse (Hoffmann, 2011: 105; Weiner, 1999: 1123, 1146-7). While there are evident limits to taking the official proclamations of the Soviet discourse at face value, its hostility to racism was arguably not hypocritical and arose out of the ideological orientation that asserted the possibility and desirability of the transformation of human nature, which logically made any naturalist essentialism the 'natural' enemy of socialism. 'Soviet power demonstrated permanently and on different levels of its political and economic practice a deep, almost instinctive aversion toward everything natural. The campaigns against genetics and psychoanalysis are as characteristic in this respect as the collectivization of 
agriculture in the 1930s, aimed at uprooting the peasants and severing their traditional, intimate attachment to the earth.' (Groys, 2011: 122. See also Dobrenko, 2007: 75-82)

The Stalinist 'Second Revolution' that received the apt name 'the Great Break' (1928-1932) was precisely the attempt to overcome the traditional forms of life sedimented as quasi-natural and thereby endow socialism, which at the time was restricted to the ideological and institutional hegemony of the Bolshevik Party, with a real existence as a positive form of life. It was precisely its attempt to force the ideology of socialism into the immanence of lived reality that made the Stalinist project biopolitical, going beyond the sovereign control of territory, the control over political institutions and even monopoly on official ideology towards the active transformation of the lived reality of the population (see Weiner, 1999: 1119-1120). The Great Break was a threepronged assault on the traditional forms of life: the forced industrialization that wiped out the remnants of private industry and trade and produced, literally from scratch, new industrial complexes and cities (see Kotkin, 1995: 106-143; Tucker, 1992: 101-115; Fitzpatrick, 2002: 40-61); the collectivization of agriculture that eliminated private farming and forced the rural population into state-owned collective farms (Conquest, 1987; Viola, 1999); the 'cultural revolution' that sought to produce a new proletarian intelligentsia to replace 'bourgeois specialists' in industry, science and art (see Fitzpatrick, 1974; David-Fox, 1999). All three processes were marked by radical social dislocations and extreme governmental violence, well summed up in the claim of Stalin's close ally Lazar Kaganovich that the Great Break consists in the 'radical destruction of all socio-economic relations, accompanied by a technical revolution, and not the other way round.' (Kaganovich cited in Priestland, 2007: 207) 
This is why Soviet socialism was from the outset radically heterogeneous to the protective, securitarian or 'immunitary' orientation that defined Western biopolitics in its 'racist' inflection (Foucault, 2007: 8-49; Esposito, 2011: 112-143). Since the object of socialist biopolitics was not life as it was but life as it must become, Stalinism did not valorize any aspect of the existing reality (be it economic exchange as in liberalism or racial vitality as in Nazism) but rather cast the existing forms of life as 'obsolete' and 'dying' - the favoured tropes of Soviet discourse of the period (see Dobrenko, 2007: 101-124, 313-327). Rather than seek to protect the race, however it is defined, from heterogeneous elements that threatened it, Stalinism renounced the task of protection altogether in the drive for radical transformation that ultimately attacked the forms of life proper to the race in question, tirelessly transforming the 'dying' into the dead.

It is from this perspective that the difference of class enemy from the racial enemy becomes clear. Even when class enemies (e.g. the representatives of the aristocracy, bourgeoisie or the clergy) were cast in the official discourse as unproductive 'parasites', 'vermin' or 'filth' that could only corrupt the victorious proletariat and hence had to be excluded from the emerging polity through the deprivation of political rights, exile or incarceration (Weiner 1999: 1121), this exclusion did not operate in strict accordance with the naturalist and evolutionary logic of racism. The task of the socialist revolution was not the protection (of the race, nation, state, etc.) against the threat of the external or internal other but the transformation of society, which would abolish the existing hierarchies and distinctions between the self and the other. The class enemy is a figure that resists this transformation: it is not a threat to the established way of life but rather the personification of this way of life itself that, by holding on to it, thwarts the triumphant progress of the revolution. While the racist logic protects the given self against the threat of the other, the logic of class 
struggle attacks the given self as 'vermin', 'filth' or 'parasite' in the name of the otherness that it must become. This is why the dominant trope of the Great Break was 'reforging', the transformation of human beings into 'new Soviet persons', and the Gulag camp was the prime site for such reforging, proudly publicized by the Soviet government as the space where the class enemy is transformed into the hero of socialist construction (see Dobrenko, 2007: 105-116). Although the violent character of such reforging is evident, its very possibility was by definition denied to the racial enemy, which makes the metaphoric transfer of the term to the discourse of class struggle highly problematic.

Racism and the Great Retreat

Perhaps, then, Foucault's notion of racism would be more applicable for the aftermath of the Great Break, the period of High Stalinism, where socialism was declared to have been built and the non-productive classes eliminated. It is indeed in this period that the Soviet regime made increasing recourse to the medico-political interventions against social deviance that Foucault analysed in terms of the logic of racism (see Hoffmann, 2011: 86-101). Yet, these interventions had nothing to do with the logic of class struggle but were rather conditioned by its decline. This decline is usually dated to the series of policy reversals in 1933-1934 that have come to be known as the Great Retreat (Timasheff, 1946), the regime's attempt at social stabilization after the paroxysms of the Great Break that tempered the apocalyptic drive of the construction of socialism in favour of a lasting compromise with the existing forms of life. This compromise took a number 
of forms, from the rehabilitation of traditional culture and pre-revolutionary history to the restoration of uniforms and ranks in the army, from the return to the pro-family and pro-natalist policy and the criminalization of abortion to the celebration of conspicuous consumption (see Tucker 1977: 95-99; Hoffmann 2011: 13-14, 143-155).

It is in this context of social stabilization and normalization that the reliance of the Soviet regime on $19^{\text {th }}$ century Western governmental technologies must be situated. Indeed, Foucault's abovediscussed examples of the valorization of Swan Lake, narrative painting and the social novel in the USSR all belong to the period of the Great Retreat and were barely conceivable in the iconoclastic context of the Cultural Revolution of the late 1920s. While Foucault was certainly correct about the use of Western biopolitical technologies, including racist ones, by the Stalinist and the postStalinist regime, he was wrong to interpret it in terms of the inherently racist character of socialist biopolitics. The fact that 'non-socialist' governmental technologies were deployed in the Soviet Union does not testify to some deep-seated inner contradiction of socialism but simply to the retreat from its dominant rationality, i.e. that of class struggle, which, as we have seen, had its own biopolitical logic that was irreducible to that of racism. In 'Society Must be Defended' Foucault alludes to the idea of the retreat in Soviet socialism in his rhetorical question: 'And what if Rome once more conquered the revolution?' (2003: 84) However contested Timasheff's idea of the Great Retreat remains in Soviet studies (see e.g. Hoffmann, 2004; Lenoe, 2004), this question may be answered in the affirmative with regard to the Soviet case. Yet, there remains a more specific question: did 'Roman' biopolitics, which Foucault defined as racist, conquer revolutionary biopolitics, or did 'Roman' biopolitics conquer the revolution that had not produced any biopolitics of its own? While Foucault opts for the latter answer, in this article we seek to argue for the 
former. The Great Retreat then becomes intelligible precisely as the moderation of the biopolitical assault on the existing forms of life, their incorporation into the new order as the instruments of its stabilization and the reorientation of governmental rationality from transforming society to securing the newly established order. It is this concern with security, conspicuous by its absence in the first two decades of socialism, that explains the recourse of the Soviet regime to the techniques borrowed from Western governmentality, for which the rationality of security has been constitutive (Foucault, 2007: 11-87) and whose biopolitical inflexion made racism possible.

The same argument applies a fortiori to the more explicit examples of Soviet discrimination and repression of ethnic minorities that Foucault did not address, e.g. the infamous 1937-1939 'national operations' against the diaspora populations, suspected of forming 'fifth columns' in the event of foreign invasion, the purges of Nazi collaborators in the newly annexed territories of the USSR after World War II or the anti-Semitic repression of 1948-1953 (Hoffmann, 2011: 295-301; van Ree, 2002: 201-207; Weiner, 1999: 1131-1140; Barnes, 2011: 231-239; Lowe, 2012: 340-358; Gellately, 2013: 193-208). These policies, whose scope and intensity only become fully known after the demise of the USSR, appear to be analogous to the racist policies of Western colonial powers or Nazi Germany and were barely mediated by the socialist ideology of class struggle. Instead they confirm the regime's retreat from its principles that became particularly pronounced after World War II and during the early Cold War, as geopolitical considerations of state security and international power politics repeatedly overrode the ideological concerns of the socialist project (cf. Weiner, 1999: 1129-1130). Of course, one should not overestimate the degree to which the 'ethnicization' of the enemy obscured political and ideological criteria: e.g. Ukrainian nationalists belonging to the Ukrainian Insurgent Army (UPA) were prosecuted as 'bourgeois 
nationalists' and not as Ukrainians, while the anti-Semitism of 1952-53 targeted specific individuals and groups as e.g. 'rootless cosmopolitans', while leaving many Jews in key positions in the Soviet state, army, industry, etc. As Amir Weiner (1999: 1155) argues, '[excision], even when totalized, did not emanate from a genocidal ideology and was not practiced through exterminatory institutions. Purification did not engage collectives as such but rather the individuals who comprised them.' Nonetheless, while it would be incorrect to interpret these policies as the triumph of nature versus nurture and hence speak of Soviet racism in the literal sense, its metaphorical deployment as the proof of the victory of Rome over the revolution certainly appears legitimate, though, as we shall demonstrate in the following section, not generalizable to the entire period of High Stalinism.

\section{Racism and the Great Terror}

We have demonstrated that Foucault's notion of racism is inapplicable for the early-Stalinist project of the construction of socialism, which rather possessed an autonomous biopolitical rationality, yet relevant for grasping the retreat from this rationality starting from the mid-1930s. Nonetheless, the area of the applicability of this notion is highly circumscribed and should not be extended to the 'High Stalinist' and post-Stalinist period. In particular, the logic of racism is illsuited to explain the most definitive instance of Soviet governmental violence in the aftermath of the Great Retreat, i.e. the Stalinist Terror peaking in 1937-1938 but lasting until 1953 . The unprecedented genocidal drive of the Great Terror makes it the paradigmatic case of the conversion of biopolitics into thanatopolitics, which Foucault analysed in the case of Nazism with the help of his notion of racism. Nonetheless, this notion is just as unhelpful for understanding the Stalinist Terror as it was for grasping the logic of class enmity during the Great Break. We need 
only compare Foucault's account of racial enmity with the notion of the 'enemy of the people' that came to replace the figure of the class enemy in the Soviet discourse in the late 1930s.

This term, whose genealogy dates back to the French Revolution, was brought into the public discourse in Stalin's speech at the fateful Central Committee plenum in February 1937, which launched the most extreme phase of the Terror (Goldmann, 2011: 73-79). This categorical change was an important indicator of the shift away from the explicitly class-based dictatorship enshrined in the 1918 and 1925 Soviet Constitutions to the ostensibly popular and even democratic political system proclaimed in the 1936 Stalin Constitution, which abolished the exclusionary measures against the 'non-productive' classes and introduced universal direct suffrage (Tucker, 1992: 441478; Hoffmann, 2011: 278-305). The 'enemy of the people' was no longer a class enemy simply because the 'non-productive' classes had already been abolished during the dismantlement of the private sector in industry and the successful collectivization process in agriculture. For this reason, the enemy could no longer have a determinate identity of its own (e.g. a kulak, aristocrat, 'bourgeois specialist'), that could invite even superficial analogies with the racial enemy of the Nazis. Instead, it could only hide behind the legitimate identity of the collective farmer, worker, army general or the member of the Central Committee. This is why since the 1930 s the enemy was usually presented as the spy of foreign powers, engaged in 'wrecking' activities of almost diabolical proportions while maintaining the appearances of the ordinary Soviet citizen (see Goldmann, 2011: 23-79).

The show trials of the 1930s demonstrated that seemingly quite normal persons were capable of strewing ground glass in the food of the workers, giving them smallpox and skin disease, poisoning wells and public places, infecting livestock with 
anthrax, and so on. Moreover, they did all this on a superhuman, unimaginable scale, accomplishing the most titanically destructive feats in many places at the same time. That the actions of the show-trial defendant defied ordinary human logic was usually even emphasized in the accusation because this inexplicability was evidence that his evil will was absolute and incorrigible and could only be subdued by physically eliminating the individual. (Groys, 2011: 61)

From that moment on, the enemy could no longer be 'reforged', hence the rapid silencing of the Gulag camps, their transformation from showcase structures of the construction of socialism into purely punitive institutions, the abandonment of pardons and early release, and the increased recourse to death penalty (Barnes, 2011: 163-165, 185-193; Weiner, 1999: 1131). While this transformation apparently brings us closer to the irredeemable nature of the racial enemy, the difference of the Stalinist 'enemy of the people' was that it could never be identified in terms of any positive predicate that could be used to separate it from the rest of the society. As a result, the entire Soviet people without exception found its elf exposed as potentially its own enemy.

Rather than invoke anything like a war of determinate races or antagonistic classes in the divided society, the logic of enmity during the Great Terror called for the tireless disconcealment of the invisible enemy within the ostensibly united and loyal society. This is why one's class (or other) identity neither resigned one to persecution nor spared one from it during these years. Insofar as the enemy was now always a 'hidden' one, it was necessary not merely to show resolve and courage in confronting it, as it was during the Civil War or the collectivization, but also to practice extreme vigilance since anyone at all could be the enemy and no positive principle of distinction, 
be it class, race, gender or profession, was of any use in revealing it. After all, the greatest proportional number of the 'enemies of the people' turned out to be found within the Central Committee of the Party itself, the majority of whose members ended up executed (Getty and Naumov, 2010; Getty, 2013). While this construction of the enemy paved the way for the paroxysmal spiral of violence that certainly approaches Nazism in its scope and intensity, its rationality is entirely inexplicable in terms of racism.

Thus, for all its merits in the Western context, Foucault's paradigm of racism does not fare well in accounting for Soviet biopolitics either in its early-Stalinist version of the Great Break or the highStalinist thanatopolitics of the Great Terror. Rather than help us understand the biopolitics of socialism, the utility of notion of racism is restricted to the phenomena that we have come to understand in terms of the retreat from socialism, be it the normalization policies of the mid1930s or the 'anti-cosmopolitan' turn of the early 1950s. While the notion of racism certainly has a place in the study of Soviet biopolitics, its generalization serves to occlude the biopolitical rationality that these racist policies retreated from, the rationality of radical social transformation through the intensification of class struggle, which forces socialism into the real as a positive form of life. In its combination of revolutionary transcendence and biopolitical immanence this rationality was clearly irreducible either to the racism of 'Society Must be Defended' or the governmentalities addressed in the subsequent courses: raison d'etat, police and liberalism (see XX for a detailed comparison). One can only speculate about Foucault's reasons for wanting to, on the one hand, deny the existence of this autonomous socialist biopolitics, and, on the other hand, associate socialism with the logic of racism that is inextricably tied to Nazism. Instead, in the 
following section we shall attempt to identify the precise point in the genealogy of racism where Foucault's analysis erred and from where the inquiry into the biopolitics of socialism may resume.

Is There a Biopolitics of Class Struggle?

In 'Society Must be Defended' Foucault reconstitutes what he calls a 'historico-political discourse' that functioned since the $17^{\text {th }}$ century as the alternative to the more familiar discourses of political philosophy, focused on the problem of sovereignty, which Foucault was famously targeting at that stage in his work. In contrast to the abstract, ahistorical and impartial discourse of political philosophy, epitomized by Hobbes, this alternative discourse, whose emergence Foucault traces in the $17^{\text {th }}$ century England (Edward Coke, John Lillburne) and early $18^{\text {th }}$ century France (Henri de Boullainvilliers), is historical through and through, arising within a particular struggle and taking up a position in it (Foucault, 2003: 268-271). It is a 'counter-history', a history that does not seek to celebrate, memorialize and reinforce sovereign power but rather seeks to undermine it by retelling the story of sovereignty as the narrative of submission and subjugation, told from below by those lacking in sovereign splendour and absent from the official history (ibid.: 66-76). Rather than represent society as a unity held together by the sovereign, the historical discourse casts society as always already binary, structured in terms of the antagonism between those in power and those lacking it, '[them] and us, the unjust and the just, the masters and those who must obey them, the rich and the poor, those who invade lands and those who tremble before them, the despots and the groaning people.' (Ibid.: 74) 
This antagonism was framed in terms of the struggle of two so-called 'races' within a society. It is important to note that the concept of 'race' in this discourse was not, in Foucault's reading, pinned to any 'stable biological meaning' (ibid.: 77) but rather designated a 'historico-political divide' between two groups in a society that did not share the same language or religion and only formed a united polity as a result of the conquest or subjugation of one by the other: 'two races exist when there are two groups, which, although they coexist, have not become mixed because of the differences, dissymmetries and barriers created by privileges, customs and rights, the distribution of wealth, or the way in which power is exercised.' (Ibid.) In contrast to the fictitious 'war of all against all' posited by Hobbes as the precondition for the institution of sovereign power, the counter-historical discourse posited real instances of war, e.g. the Norman conquest, as the actual foundation of state power and the real conflict between the conquerors and the conquered (e.g. the Normans and the Saxons in England, the Germanic aristocracy and the GalloRoman bourgeoisie in France) as the true substance of politics and history. We are evidently a long way from the modern notion of racism - if anything, the function of the counter-historical discourse in its original formulation in the English radicalism of the $17^{\text {th }}$ century is closer to what we would today call a 'revolutionary' discourse of emancipation.

Indeed, in Foucault's own genealogy, this counter-historical discourse served as one of the precursors of the explicit revolutionary discourse in $18^{\text {th }}$ century France and beyond:

What could the revolutionary project and the revolutionary idea possibly mean without this preliminary interpretation of the dissymmetries, the disequilibriums, the injustice and the violence that function despite the order of laws, beneath the order of laws, and through and because of the order of laws? Where would the 
revolutionary project, the revolutionary idea, or revolutionary practice be without the will to rekindle the real war that once went on and which is still going on? What would the revolutionary project and revolutionary discourse mean if the goal were not a certain, a final, inversion of relations of power and a decisive displacement within the exercise of power? (Ibid.: 78-79)

During the $19^{\text {th }}$ century the counter-historical discourse split into two tendencies, the 'properly revolutionary' discourse of class struggle that maintained the historical orientation of the earlier discourse but replaced its 'races' with socioeconomically defined classes, and the 'properly racist' discourse, which replaced the historical approach with the quasi-scientific, biological and evolutionary one, thus recoding the historical war as the struggle of the race for existence. While the discourse of class struggle maintained its predecessor's function of undermining the stability of the state form, recovering and reactivating the historical war and the 'binary society' that gave rise to it, the racist, biologico-medical discourse began to serve the contrary function of the stabilization of social order, recasting the binary society as a monistic one, which was nonetheless threatened by heterogeneous elements that must be eradicated for the life of the race to be secure. As a result of this recasting, the state, which for the early counter-historical discourse was an instrument of the oppression of one race by another, becomes the 'protector of the integrity, the superiority and the purity of the race. The idea of racial purity, with all its monistic, Statist and biological implications: that is what replaces the idea of race struggle.' (Ibid.: 81) In this manner, counter-history ends up reclaimed by the traditional history of sovereignty and the protorevolutionary discourse is converted into the anti-revolutionary discourse of state racism: 
Racism is, quite literally, revolutionary discourse in an inverted form. Whereas the discourse of races, of the struggle between races, was a weapon to be used against the historico-political discourse of Roman sovereignty, the discourse of race (in the singular) was a way of turning that weapon against those who had forged it, of using it to preserve the sovereignty of the State, a sovereignty whose lustre and vigour were no longer guaranteed by magico-juridical rituals but by medico-normalizing techniques. Thanks to the shift from law to norm, from races in the plural to race in the singular, from the emancipatory project to a concern with purity, sovereignty was able to invest or take over the discourse of race struggle and reutilize it for its own strategy. State sovereignty thus becomes the imperative to protect the race. It becomes both an alternative to and a way of blocking the call for revolution that derived from the old discourse of struggles, interpretations, demands and promises. (Ibid.: 82)

Thus, the original discourse of the struggle of the races ends up split into the revolutionary discourse of struggle (without races) and the 'neo-Roman' counter-revolutionary discourse of the protection of the race. At first glance, this split suggests the possibility of two distinct forms of biopolitics correlative with these two strands: the biopolitics of class struggle (socialism) and the biopolitics of racism (Nazism). Instead, Foucault immediately effaces this difference by subsuming the former under the latter as its metaphorical version. While the Nazi discourse reinserts the biological logic of state racism into the mythical and archaic context of the war of the races, in the Soviet discourse the insertion of the theme of class struggle into the biopolitical context allegedly produces a quasi-scientific, medico-psychiatric interpretation of racism. What was at first 
constructed as an alternative to racism, whereby history was grasped as the conflict of classes without a racial dimension to it, somehow becomes a form of racism, apparently all the more insidious because there was no actual reference to race in it.

[Soviet racism] consists in reworking the revolutionary discourse of social struggles the very discourse that derived so many of its elements from the old discourse of the race struggle - and articulating it with the management and the policing that ensure the hygiene of an orderly society. And the hoarse songs of the races that clashed in battles over the lies of laws and kings, and which were after all the earliest form of revolutionary discourse, become the administrative prose of a State that defends itself in the name of social heritage that has to be kept pure. (Ibid.: 83)

The question that has not been but can be raised within the Foucauldian genealogical framework is whether biopower must exclusively latch onto the state racism, which is only one descendant of the counter-historical discourse of race struggle or whether it may also be exercised on the basis of the second descendant, i.e. the discourse of class struggle. After all, if racism was the 'inversion' of revolutionary discourse, what is the biopolitical content of that which it inverted? While, as we have seen, Foucault found the absence of an autonomous governmentality and biopolitics in socialism its key problem, explaining its internal contradictions and paroxysmal violence, this perception may well be the effect of a prior closure of biopolitics within the horizon of racism. Having excluded the possibility of a revolutionary biopolitics grounded in class struggle, one can either conclude that socialism lacks a biopolitical rationality as such or that it shares the rationality of racism with its ideological antagonists. Both conclusions are unhelpful for grasping the Soviet project and the governmental violence that accompanied it, the former effacing the specificity of 
this violence, irreducible to the traditional sovereign power of death, and the latter putting the blame for it on the rationality that was quite peripheral to this project. Perhaps, Foucault left out the revolutionary discourse out from his analysis of biopolitics because its orientation towards the transcendence of the old world conflicts with the immanentist logic of biopolitics. Yet, just as it was possible to combine the negative power of sovereignty with the productive orientation of biopolitics in the 'demonic project' of state racism, Stalinism demonstrates the possibility of combining the transcendence of revolution with the immanentism of biopower in a project of forcing the idea of socialism into lived reality that was equally demonic yet entirely distinct from racism. 


\section{REFERENCES}

Barnes, S. (2011) Death and Redemption: The Gulag and the Shaping of Soviet Society. Princeton: Princeton University Press.

Collier, S. (2009) 'Topologies of Power: Foucault's Analysis of Political Government beyond 'Governmentality', Theory, Culture and Society 26(6): 78-108.

Collier, S. (2011) Post-Soviet Social: Neoliberalism, Social Modernity, Biopolitics. Princeton: Princeton University Press.

Conquest, R. (1987) The Harvest of Sorrow: Soviet Collectivization and the Terror-Famine. Oxford: Oxford University Press.

David-Fox, M. (1999) 'What is Cultural Revolution?' The Russian Review 58: 181-201.

Dobrenko, E. (2007) The Political Economy of Socialist Realism. New Haven: Yale University Press.

Engelstein, L. (1993) 'Combined Underdevelopment: Discipline and the Law in Imperial and Soviet Russia'. American Historical Review 98 (2): 338-353.

Esposito, R. (2008) Bios: Biopolitics and Philosophy. Minneapolis: University of Minnesota Press.

Esposito, R. (2011) Immunitas: The Protection and Negation of Life. London: Polity.

Fitzpatrick, S. (1974) 'Cultural Revolution in Russia: 1928-1932'. Journal of Contemporary History 9 (1): 33-52. 
Fitzpatrick, S. (2002) Everyday Stalinism: Ordinary Life in Extraordinary Times. Oxford: Oxford University Press.

Foucault, M. (1977) Discipline and Punish: The Birth of the Prison. New York: Knopf.

Foucault, M. (1980a) 'Questions of Geography'. In Power/Knowledge: Selected interviews and Other Writings: 1972-1977. New York: Knopf, pp. 63-77.

Foucault, M. (1980b) 'Questions of Geography'. In Power/Knowledge: Selected interviews and Other Writings: 1972-1977. New York: Knopf, pp. 63-77.

Foucault, M. (1982) 'The Subject and Power'. In H. Dreyfus and P. Rabinow, Michel Foucault: Beyond Structuralism and Hermeneutics. Chicago: University of Chicago Press, pp. 208-226.

Foucault, M. (1988a) 'Confinement, Psychiatry, Prison'. In L.D. Kritzman (ed.), Michel Foucault: Politics, Philosophy, Culture. Interviews and Other Writings: 1977 -1984. London: Routledge, pp. 178-210.

Foucault, M. (1988b) 'Politics and Reason' in L.D. Kritzman (ed.), Michel Foucault: Politics, Philosophy, Culture. Interviews and Other Writings: 1977 -1984. London: Routledge, pp. $57-85$.

Foucault, M. (1990) History of Sexuality. Volume One: An Introduction. Harmondsworth: Penguin.

Foucault, M (1994a) 'Crimes et châtiments en U.R.S.S. et Ailleurs', in M. Foucault, Dits et Écrits, tome III: 1976-1979. Paris: Gallimard, pp. 63-77.

Foucault, M. (1994b) 'La Philosophie Analytique du Pouvoir' in M. Foucault, Dits et Écrits, tome III: 1976-1979. Paris: Gallimard, pp. 535-541.

Foucault, M. (2003) 'Society Must be Defended': Lectures at the College de France 1975-1976. London: Picador.

Foucault, M. (2007) Security, Territory, Population: Lectures at the College de France 1977-1978. Basingstoke: Palgrave. 
Foucault, M. (2008) The Birth of Biopolitics: Lectures at the College de France 1978-1979. Basingstoke: Palgrave.

Foucault, M. (2011) The Courage of Truth: Lectures at the College de France 1983-1984. Basingstoke: Palgrave.

Gellately, R. (2013) Stalin's Curse: Battling for Communism in War and Cold War. Oxford: Oxford University Press.

Getty, A. and Naumov, O. (2010) The Road to Terror: Stalin and the Self-Destruction of the Bolsheviks: 1932-1939. New Haven: Yale University Press.

Getty, A. (2013) Practicing Stalinism: Bolsheviks, Boyars and the Persistence of Tradition. New Haven: Yale University Press.

Groys, B. (2011) The Total Art of Stalinism. London: Verso.

Hoffmann, D. (2004) 'Was There a "Great Retreat" from Soviet Socialism? Stalinist Culture Reconsidered'. Kritika: Explorations in Russian and Eurasian History 5 (4): 651-674.

Hoffmann, D. (2011) Cultivating the Masses: Modern State Practices and Soviet Socialism: 19141939. Ithaca: Cornell University Press.

Hoffmann, M. (2014) Foucault and Power: The Influence of Political Engagement on the Theories of Power. London: Bloomsbury.

Kharkhordin, O. (1999) The Collective and the Individual in Russia: A Study of Practices. Berkeley: Berkeley University Press.

Kharkhordin, O. (ed.) (2001) Michel Foucault i Rossiya. St.Petersburg: Letni Sad.

Kotkin, S. (1995) Magnetic Mountain: Stalinism as a Civilization. Berkeley: The University of California Press.

Lemke, T. (2011) Biopolitics: An Advanced Introduction. New York: New York University Press. 
Lenoe, M. (2004) 'In Defense of Timasheff's Great Retreat'. Kritika: Explorations in Russian and Eurasian History 5 (4): 721-730.

Losurdo, D. (2004) 'Towards a Critique of the Category of Totalitarianism'. Historical Materialism $12(2): 25-55$.

Lowe, K. (2012) Savage Continent: Europe in the Aftermath of World War II. New York: St. Martin's Press.

Plamper, J. (2002) 'Foucault's Gulag'. Kritika: Explorations in Russian and Eurasian History 3 (2): 255-280.

Priestland, D. (2007) Stalinism and the Politics of Mobilization: Ideas, Power and Terror in Interwar Russia. Oxford: Oxford University Press.

van Ree, E. (2002) The Political Thought of Joseph Stalin: A Study in Twentieth-Century Revolutionary Patriotism. London: Routledge.

Said, E. (1988) 'Michel Foucault, 1926-1984'. In J. Arac (ed.), After Foucault: Humanistic Knowledge, Postmodern Challenges. New Brunswick, NJ: Rutgers University Press, pp. 1-11.

Simon, J. (1971) 'A Conversation with Michel Foucault'. Partisan Review 38 (2): 196-201.

Timasheff, N. (1946) The Great Retreat: The Growth and Decline of Communism in Russia. New York: E.P. Dutton and Company.

Tismaneanu, V. (2012) The Devil in History: Communism, Fascism and Some Lessons of the Twentieth Century. Berkeley: University of California Press.

Tucker, R. (1992) Stalin in Power: The Revolution from Above 1928-1941. New York: W.W. Norton. Viola, L. (1999) Peasant Rebels Under Stalin: Collectivization and the Culture of Peasant Resistance. Oxford: Oxford University Press. 
Weiner, A. (1999) 'Nature, Nurture, and Memory in a Socialist Utopia: Delineating the Soviet Socio-Ethnic Body in the Age of Socialism', The American Historical Review 104(4): 11141155. 